\title{
The Transition Period Updated: A Review of the New Insights into the Adaptation of Dairy Cows to the New Lactation
}

\author{
Matteo Mezzetti ${ }^{1}\left(\mathbb{D}\right.$, Luca Cattaneo $^{1}{ }^{1}$, Matilde Maria Passamonti ${ }^{1}$, Vincenzo Lopreiato ${ }^{1} \oplus$, Andrea Minuti ${ }^{1}(\mathbb{D}$ \\ and Erminio Trevisi 1,2,*(D) \\ 1 Department of Animal Sciences, Food and Nutrition (DIANA), Facoltà di Scienze Agrarie, Alimentari e \\ Ambientali, Università Cattolica del Sacro Cuore, 29122 Piacenza, Italy; matteo.mezzetti@unicatt.it (M.M.); \\ luca.cattaneo@unicatt.it (L.C.); matildemaria.passamonti1@unicatt.it (M.M.P.); \\ vincenzo.lopreiato@unicatt.it (V.L.); andrea.minuti@unicatt.it (A.M.) \\ 2 Romeo and Enrica Invernizzi Research Center for Sustainable Dairy Production, Università Cattolica del \\ Sacro Cuore (CREI), 29122 Piacenza, Italy \\ * Correspondence: erminio.trevisi@unicatt.it; Tel.: +39-0523-599278; Fax: +39-0523-599276
}

check for updates

Citation: Mezzetti, M.; Cattaneo, L.; Passamonti, M.M.; Lopreiato, V.; Minuti, A.; Trevisi, E. The Transition Period Updated: A Review of the New Insights into the Adaptation of Dairy Cows to the New Lactation. Dairy 2021, 2, 617-636. https:// doi.org/10.3390/dairy2040048

Academic Editors: Burim Ametaj and Sven Dänicke

Received: 6 September 2021

Accepted: 20 October 2021

Published: 3 November 2021

Publisher's Note: MDPI stays neutral with regard to jurisdictional claims in published maps and institutional affiliations.

Copyright: (c) 2021 by the authors. Licensee MDPI, Basel, Switzerland. This article is an open access article distributed under the terms and conditions of the Creative Commons Attribution (CC BY) license (https:/ / creativecommons.org/licenses/by/ $4.0 /)$.

\begin{abstract}
Recent research on the transition period (TP) of dairy cows has highlighted the pivotal role of immune function in affecting the severity of metabolic challenges the animals face when approaching calving. This suggests that the immune system may play a role in the etiology of metabolic diseases occurring in early lactation. Several studies have indicated that the roots of immune dysfunctions could sink way before the "classical" TP (e.g., 3 weeks before and 3 weeks after calving), extending the time frame deemed as "risky" for the development of early lactation disorders at the period around the dry-off. Several distressing events occurring during the TP (i.e., dietary changes, heat stress) can boost the severity of pre-existing immune dysfunctions and metabolic changes that physiologically affect this phase of the lactation cycle, further increasing the likelihood of developing diseases. Based on this background, several operational and nutritional strategies could be adopted to minimize the detrimental effects of immune dysfunctions on the adaptation of dairy cows to the new lactation. A suitable environment (i.e., optimal welfare) and a balanced diet (which guarantees optimal nutrient partitioning to improve immune functions in cow and calf) are key aspects to consider when aiming to minimize TP challenges at the herd level. Furthermore, several prognostic behavioral and physiological indicators could help in identifying subjects that are more likely to undergo a "bad transition", allowing prompt intervention through specific modulatory treatments. Recent genomic advances in understanding the linkage between metabolic disorders and the genotype of dairy cows suggest that genetic breeding programs aimed at improving dairy cows' adaptation to the new lactation challenges (i.e., through increasing immune system efficiency or resilience against metabolic disorders) could be expected in the future. Despite these encouraging steps forward in understanding the physiological mechanisms driving metabolic responses of dairy cows during their transition to calving, it is evident that these processes still require further investigation, and that the $\mathrm{TP}$-likely extended from dry-off—continues to be "the final frontier" for research in dairy sciences.
\end{abstract}

Keywords: metabolic disorders; immune dysfunctions; inflammation; parturition; transition management

\section{Introduction}

Considerable literature exists on the severe challenges faced by dairy cows at their transition from calving to lactation. Most studies focus on the transition period (TP) phase, which begins three weeks before calving and spans the first three weeks of lactation [1]. Typically, this physiological phase implies severe alterations in the metabolic asset of dairy cows. These alterations are driven by sudden changes in hormonal trends and nutrient partitioning $[2,3]$ as well as by the adaptation of the animal's metabolism to the 
negative energy and protein balance conditions driven by late pregnancy and early lactation requirements [4-9]. Dairy cows are also prone to developing immune dysfunctions in this phase. Such dysfunctions consist of two phenomena: (1) a reduced competence of the immune system, triggering a hypo-responsive state in polymorphonuclear cells (PMN) and lymphocytes starting about 2-3 weeks before calving, and reaching lowest efficiencies between the time of calving and two days after [10-12], and (2) the occurrence of systemic inflammation that triggers the acute phase response after parturition [13]. Recently, Lopreiato et al [14] reported that increasing the release of proinflammatory cytokines (PICs-interleukin-6 and interleukin-1 $\beta$ ) upon PEG-rbG-CSF treatment in dairy cows after parturition did not result in increased systemic inflammation (as reflected by haptoglobin and ceruloplasmin plasma levels). This latter finding highlights that mechanisms and/or molecules other than PICs are likely to drive the acute phase response occurring in dairy cows after parturition. Thus, despite reduced competence of the immune system and systemic inflammation commonly appear together in dairy cows at their transition to calving [15], these should be probably considered as two distinct phenomena. A recent review [16] hypothesizes that a multifactorial etiology could be responsible for these dysfunctions and that their severity is directly related to the magnitude of metabolic changes faced by dairy cows. Together, these metabolic and immunologic challenges during the peripartal period are important factors that limit the ability of most cows to achieve optimal performance and balanced immune-metabolic status in early lactation.

The risk ratio of both metabolic and infectious diseases in early lactation is directly related to the magnitude of metabolic alteration and the degree of immune dysfunction faced by dairy cows during the periparturient period [17-19]. In turn, the occurrence of disease (infectious and/or metabolic) in this physiological phase could further challenge the metabolism of dairy cows and impair the function of leukocytes, increasing the likelihood of other diseases $[20,21]$. This vicious circle increases drug costs and could impair fertility of the animals, frequently resulting in their culling $[22,23]$.

Considerable research efforts have focused on providing best management strategies to reduce the detrimental effects of a "bad transition" on early lactating cows. However, recent studies have hypothesized that the roots of health problems occurring at the onset of lactation could sink way before the "conventional" TP, and that a wider perspective on the management of the transition to calving could improve the adaptation of dairy cows to the new lactation. For this reason, the present review provides a new perspective on the metabolic challenges and immune dysfunctions faced by transition dairy cows. The aim is to extend the focus of dairy farmers towards a wider time frame as compared to the "conventional" TP. As such, several strategies to optimize the onset of lactation are reviewed from a holistic standpoint.

\section{The Connection between Inflammation, Immune Dysfunctions, and Metabolic Disorders: Which Is the Driving Cause?}

Metabolic disorders affecting early lactating cows are a relevant concern in modern dairy herds as they have the potential to affect farmers' incomes through increasing drug costs and decreasing milk yields [20,21]. Dairy cows affected by a metabolic disorder in early lactation often develop several other diseases within a short time frame; this makes the identification of the etiology of such disorders a challenging issue. As such, prevention may be the best strategy to address metabolic disorders in early lactation. Recently, considerable research has suggested that prepartal immune dysfunctions and systemic inflammation serve as predisposing factors in the etiology of metabolic disorders in early lactation. Thus, understanding the mechanism driving prepartal immune dysfunctions could improve the capacity to prevent disease occurrence.

\subsection{Prepartal Immune Dysfunctions and Metabolic Disorders: The Ketosis Model}

Ketosis is a widely discussed metabolic disease affecting early lactating cows. Its etiology is classically referred to as a severe negative energy balance (NEB) condition affecting dairy cows immediately before or after calving. Recently, Mezzetti et al. [24] 
performed a retrospective analysis to detect subclinical ketosis (SCK) in postpartum dairy cows (blood $\beta$-hydroxybutyrate-BHB-higher than $1.2 \mathrm{mmol} / \mathrm{L}$ ) and tested the relationship between the onset of SCK in early lactation and trends of plasma analytes during the dry period. Prepartal trends of plasma analytes in cows affected by SCK in early lactation revealed an inflammatory condition, impairment of kidney functions, and liver damage occurring several weeks before calving. These trends in plasma analytes were consistent with those observed by another study in the same phase [25]. Furthermore, leukocytes from cows affected by SCK in early lactation had a greater production of interferon- $\gamma$ (IFN- $\gamma$ ) during the dry period in response to an ex-vivo challenge with Mycobacterium avium [26]. These alterations of plasma analytes and increased IFN- $\gamma$ production by leukocytes preceding SCK in dairy cows were similar to those affecting women during preeclampsia [27,28]. Mezzetti et al. [24] also observed that leukocytes from cows affected by SCK in early lactation had lower production of proinflammatory cytokines (PICs) during the dry period in response to an ex-vivo challenge with lipopolysaccharides (LPS).

In this scenario, a linkage between altered immune functions during the dry period and the occurrence of SCK in early lactation is probable. The transient unresponsive state of leukocytes against endotoxin challenges, known as endotoxin tolerance status [13], is likely driven by the suppression of genes related to cell survival as well as the upregulation of anti-inflammatory genes in these cells. These could be driven by the systemic inflammatory condition observed during the dry period in cows developing SCK in early lactation. Greater IFN- $\gamma$ production from leukocytes consequential to their activation may induce insulin resistance during the dry period [29], thus accounting for the simultaneous increase of plasma concentrations of glucose, nonesterified fatty acids (NEFA), and BHB before calving. The high circulating glucose levels and the anorexic power exerted by high circulating NEFA, BHB, and PICs concentrations could reduce feed intake around calving [30]. Such a feed intake depression, together with the energy requirement related to the activation of the immune system in the dry period, worsen the NEB in early lactation $[7,31]$. Severe NEB in early lactation induces milk yield losses and boosts the mobilization of lipid sources, increasing the NEFA load on liver metabolism. Despite this, the oxidizing capacity of the liver against NEFA in early lactation is impaired due to the metabolic preeclamptic-like status occurring during the dry period, and this could boost the release of ketone bodies. The onset of a ketosis status in early lactation could increase the impairment of leukocyte function detected during the dry period, due to a combination of higher lipomobilization [32,33] and greater expression of anti-inflammatory genes at the liver level to cope with inflammation and to prevent fatty liver condition [34]. This was confirmed by Minuti et al. [35] who found an inhibitory effect on transcriptomic pathways related to cell cycle, DNA replication, and repair in circulating leukocytes from ketotic cows, likely driven by high circulating BHB levels.

Severe NEB conditions at the onset of lactation could be hypothesized as a common denominator in all metabolic disorders affecting dairy cows in early lactation $[4,36]$. Thus, the role exerted by altered immune function during the dry period in the SCK model (i.e., an immune response activation occurring before calving and followed by a transient immune suppressive status) could likely extend to other early lactation diseases [37]. This is consistent with outcomes of a previous research [38] showing that cows with high plasma PICs concentrations before calving had a reduced feed intake in the whole $\mathrm{TP}$, and a higher incidence of metabolic diseases in early lactation compared to cows having low plasma PICs concentrations before calving.

\subsection{The Role of Dry-Off on Immune Dysfunctions}

Dry-off is accompanied by alterations in the redistribution of nutrients, changes in the rumen conformation and in the mammary gland physiology [39-41]. These are typically paired with psychological challenges related to feed restrictions and the modification of social structure after regrouping [42]. A fundamental role of dry-off in the development of immune dysfunctions and systemic inflammations occurring in TP has also been hy- 
pothesized [13]. Mezzetti et al. [43] found that dry-off induces a systemic inflammation in dairy cows, and that cows with an average milk yield higher than $15 \mathrm{~L} / \mathrm{d}$ in the last week prior to dry-off face the most severe inflammatory conditions at milking interruption. It has been hypothesized that inflammatory conditions occurring after dry-off could arise from the contribution of leukocytes in the involution phase of the mammary gland [41]. Additionally, deeper metabolic changes observed in high yielding cows could be driven by greater amounts of milk and parenchymatic tissue being reabsorbed in their mammary glands [44]. Such new perspectives on the inflammatory conditions affecting dairy cows at dry-off suggest a potential contribution of this management practice to the etiology of immune dysfunctions occurring during TP. In this scenario, high PIC levels at dry-off could induce the dysfunctional activation of dendritic cells [45], inhibiting the antiphlogistic role of T-lymphocytes and predisposing dairy cows to developing systemic inflammations. Furthermore, the exposure of leukocytes to biological stressors at milking interruption could likely trigger endotoxin tolerances [46]. These phenomena, paired with the immune suppressive effect of cortisol released at dry-off as a consequence of metabolic stresses [47], could account for the reduced responsiveness of leukocytes reported during the dry period [10].

\subsection{A Potential Genetic Contribution on the Likelihood of Developing Systemic Inflammations}

Although systemic inflammations occurring at the halting of milk removal potentially contribute to altering the function of leukocytes during the dry period, recent research dismisses the dry-off as the primary cause of the immune dysfunctions affecting transition dairy cows. Cattaneo et al. [22] demonstrated that, besides the systemic inflammation triggered by dry-off, pre-existing inflammatory conditions might significantly affect the success of the dry period and early lactation. Here, cows were followed from 7 days before dry-off to 28 days after calving and retrospectively divided into three groups according to their albumin/globulin ratio (AGR) before dry-off. Compared with cows having the lowest AGR (reflecting the highest inflammatory condition before dry-off), cows with the highest AGR showed lower inflammation through the dry period and up to the first month of lactation. Furthermore, these cows had a lower somatic cell count (SCC) and better productive and reproductive performances in the subsequent lactation. These outcomes demonstrate that a mild inflammatory status could occur in some dairy cows since the late lactation phase and that these animals face greater metabolic challenges during the transition to the new lactation. A clear explanation behind the mechanism responsible for the onset of such an early and persistent inflammatory condition in some animals still lacking. Recently, Milanesi et al. [48] found the expression of two inflammatory biomarkers related to the acute phase response (paraoxonase and ceruloplasmin) to be primarily under cis regulation in dairy cattle. This significant genetic association was identified in two dairy breeds (Italian Holstein and Italian Simmental), characterized by highly different selection histories, immune-metabolic status and production performances [49-51]. Thus, a different expression of inflammatory biomarkers driven by genotype could account for the different inflammatory conditions found by Cattaneo et al. [22] before the dry-off. Despite that, the relationship between the candidate causative variants identified by Milanesi et al. [48] and the animals' performances during the TP has not yet been investigated, and the contribution of genotype on the successful adaptation of dairy cows to the new lactation still to be elucidated.

\section{Distressing Events Accrue the Severity of Immune and Metabolic Challenges during the Transition Period}

Although the driving cause of immune dysfunctions occurring during the late gestation phase remains unclear, negative effects of these on the metabolism of early lactating cows depend on several potentially harmful stimuli occurring during the TP-these may have additive effects. Some of these stimuli are driven by physiological changes occurring in the metabolism of dairy cows around the calving time: repolarization of the immune cells to maintain the pregnancy status, as well as alterations to hormonal patterns, nutrient 
availability, and redox balance [2,4,52-55]. Others are driven by psychological factors related to regrouping procedures adopted around the calving time [42]. In fact, psychological stress can significantly affect feeding and lying behaviors, severely impairing animal health and performance, in particular in subordinate cows [56]. It can also affect the hypothalamus, boosting the release of PICs [57]. Besides these unavoidable stressors, several distressing events could increase the degree of immune dysfunction during the TP, boosting the severity of metabolic challenges affecting dairy cows at the onset of lactation.

\subsection{The Role of Energy Level and Diet Changes on Innate Immune Response}

A dietary factor that could potentially affect dairy cows' adaptation to the new lactation is the energy density of the ration administered, especially during the far-off phase. Overfeeding dairy cows during this phase could boost adipose tissue deposition. A recent study [58] found that overfeeding dairy cows through the administration of dry rations containing $150 \%$ of NRC energy requirements could increase lipid deposition and induce severe changes in adipose tissue-mediated gene expression. The pathways related to lipid deposition, insulin sensitivity, and immune functions displayed the most significant changes, suggesting overfeeding during the dry period to be a predisposing factor for lipid mobilization-related metabolic disorders and immune dysfunctions in early lactation. This confirms previous observations of the Drackley's group [59-61] and supports the hypothesis that a prolonged excess of energy could induce a low-grade systemic inflammation in cows [62], similar to the "metaflammation" state reported in humans which is associated with obesity and chronic diseases [63].

Besides the contribution of energy level in affecting leukocyte function, another dietary factor that could impair immune functions of dairy cows while approaching the new lactation is the contribution of diet changes in affecting gastrointestinal tract (GIT) integrity. Physiologically, the adaptation of rumen volume to the fetal growth (before calving) and the empty uterus (in early lactation) lead to sudden changes in the passage rate of digesta across the GIT of dairy cows around calving [64,65]. Paired with this, dairy cows raised in commercial TMR systems typically undergo 3 or 4 important changes in diet composition from dry-off to early lactation (Table 1), to fit with relevant changes in their requirements [66].

Table 1. Performances inputs, dietary recommendations, and sample diets for a medium-performance dairy cow undergoing the lactation, far-off, close-up and fresh phases (adapted from NRC [67]).

\begin{tabular}{|c|c|c|c|c|c|}
\hline \multirow{2}{*}{ Item $^{1}$} & \multirow{2}{*}{ Unit } & \multicolumn{4}{|c|}{ Phase } \\
\hline & & Lactation & Far-Off & Close-Up ${ }^{4}$ & Fresh \\
\hline \multicolumn{6}{|l|}{ Inputs } \\
\hline Days $^{2}$ & day & 90 & 240 & 270 & 11 \\
\hline Body weight ${ }^{3}$ & $\mathrm{~kg}$ & 680 & 730 & 751 & 680 \\
\hline BCS & - & 3 & 3.3 & 3.3 & 3.3 \\
\hline Age & months & 49 & 57 & 58 & 58 \\
\hline Milk production & $\mathrm{kg}$ & 35 & - & - & 35 \\
\hline Butterfat & $\%$ & 3.5 & - & - & 3.5 \\
\hline True protein & $\%$ & 3 & - & - & 3 \\
\hline Lactose & $\%$ & 4.8 & - & - & 4.8 \\
\hline Dry matter intake & $\mathrm{kg}$ & 23.6 & 14.4 & 13.7 & 15.6 \\
\hline Daily weight change & $\mathrm{kg}$ & 0.3 & 0.67 & 0.67 & -1.6 \\
\hline Days to gain one condition score & day & 316 & na & na & - \\
\hline Days to lose one condition score & day & - & na & na & 55 \\
\hline \multicolumn{6}{|l|}{ Dietary recommendations } \\
\hline $\mathrm{NE}_{\mathrm{L}}$ & Mcal/day & 34.8 & 14 & 14.4 & 34.8 \\
\hline $\mathrm{NE}_{\mathrm{L}}$ & $\mathrm{Mcal} / \mathrm{kg} \mathrm{DM}$ & 1.47 & 0.97 & $1.54-1.62$ & 2.23 \\
\hline MP & g/day & 2407 & 871 & 910 & 2157 \\
\hline
\end{tabular}


Table 1. Cont.

\begin{tabular}{|c|c|c|c|c|c|}
\hline \multirow{2}{*}{ Item $^{1}$} & \multirow{2}{*}{ Unit } & \multicolumn{4}{|c|}{ Phase } \\
\hline & & Lactation & Far-Off & Close-Up ${ }^{4}$ & Fresh \\
\hline Diet MP & $\%$ & 10.2 & 6 & 6.6 & 13.8 \\
\hline RDP & g/day & 2298 & 1114 & 1358 & 1634 \\
\hline Diet RDP & $\%$ & 9.7 & 7.7 & 9.9 & 10.5 \\
\hline RUP & g/day & 1291 & 317 & 172 & 1405 \\
\hline Diet RUP & $\%$ & 5.5 & 2.2 & 1.3 & 9 \\
\hline Diet NDF min & $\%$ & $25-33$ & 33 & 33 & $25-33$ \\
\hline Diet ADF min & $\%$ & $17-21$ & 21 & 21 & $17-21$ \\
\hline Diet NFC max & $\%$ & $36-44$ & 42 & 43 & $36-44$ \\
\hline Absorbable Ca & g/day & 65 & 18.1 & 21.5 & 64 \\
\hline Diet Ca & $\%$ & 0.61 & 0.44 & $0.45(0.5-1.5)$ & 0.79 \\
\hline Absorbable P & g/day & 56.5 & 19.9 & 20.3 & 49 \\
\hline Diet $P$ & $\%$ & 0.35 & 0.22 & $0.3-0.4$ & 0.42 \\
\hline Diet $\mathrm{Mg}$ & $\%$ & 0.19 & 0.11 & 0.35-0.4 & 0.29 \\
\hline Diet $\mathrm{Cl}$ & $\%$ & 0.26 & 0.13 & $0.15(0.8-1.2)$ & 0.4 \\
\hline Diet K & $\%$ & 1.04 & 0.51 & 0.52 & 1.24 \\
\hline Diet $\mathrm{Na}$ & $\%$ & 0.23 & 0.1 & 0.1 & 0.34 \\
\hline Diet S & $\%$ & 0.2 & 0.2 & $0.2(0.3-0.4)$ & 0.2 \\
\hline Diet Co & $\mathrm{mg} / \mathrm{kg} \mathrm{DM}$ & 0.11 & 0.11 & 0.11 & 0.11 \\
\hline Diet $\mathrm{Cu}$ & $\mathrm{mg} / \mathrm{kg} \mathrm{DM}$ & 11 & 12 & 13 & 16 \\
\hline Diet I & $\mathrm{mg} / \mathrm{kg} \mathrm{DM}$ & 0.5 & 0.4 & 0.4 & 0.77 \\
\hline Diet Fe & $\mathrm{mg} / \mathrm{kg} \mathrm{DM}$ & 15 & 13 & 13 & 22 \\
\hline Diet Mn & $\mathrm{mg} / \mathrm{kg} \mathrm{DM}$ & 14 & 16 & 18 & 21 \\
\hline Diet Se & $\mathrm{mg} / \mathrm{kg} \mathrm{DM}$ & 0.3 & 0.3 & 0.3 & 0.3 \\
\hline Diet Zn & $\mathrm{mg} / \mathrm{kg} \mathrm{DM}$ & 48 & 21 & 22 & 73 \\
\hline Diet vitamin A & IU/kg DM & 3169 & 5576 & 6030 & 4795 \\
\hline Diet vitamin D & $\mathrm{IU} / \mathrm{kg} \mathrm{DM}$ & 864 & 1520 & 1644 & 1308 \\
\hline Diet vitamin E & $\mathrm{IU} / \mathrm{kg} \mathrm{DM}$ & 23 & 81 & 88 & 35 \\
\hline DCAD & meq/kg DM & na & na & $10(-75$ to 0$)$ & na \\
\hline \multicolumn{6}{|c|}{ Sample diet (ingredients listed as kg/day DM) } \\
\hline Corn silage, normal & - & 8.21 & - & $5.55(5.40)$ & 36.44 \\
\hline Grass silage, mid-maturity & - & - & 8.1 & $2.48(2.42)$ & - \\
\hline Legume forage silage, mid-maturity & - & 4.57 & - & - & - \\
\hline Legume forage hay, immature & - & - & - & - & 20.17 \\
\hline Grass hay, mid-maturity & - & 3.21 & - & - & - \\
\hline Sugar beet pup, dried & - & - & - & $2.15(2.09)$ & - \\
\hline Corn grain, steam flaked & - & 4.33 & - & - & 18.29 \\
\hline Soybean meal, $48 \% \mathrm{CP}$ & - & 1.62 & - & $0.79(0.77)$ & 2.53 \\
\hline Soybean meal, expellers & - & - & - & - & 7.65 \\
\hline Blood meal, ring dried & - & - & - & - & 1.02 \\
\hline Cottonseed, whole with lint & - & - & - & - & 8.41 \\
\hline Calcium soaps of fatty acids & - & - & - & - & 0.65 \\
\hline Vitamin and mineral premix & - & 0.49 & 0.02 & $0.43(0.42)$ & 3.18 \\
\hline Calcium carbonate & - & 0.07 & 0.46 & - & 0.56 \\
\hline Calcium phosphate (di-) & - & - & - & $0.05(0.03)$ & - \\
\hline Calcium chloride & - & - & - & $-(0.14)$ & - \\
\hline Monosodium phosphate & - & 0.02 & - & $-(0.07)$ & 0.4 \\
\hline Sodium chloride & - & 0.011 & 5.79 & 0.03 & 0.7 \\
\hline Magnesium oxide & - & - & - & $0.05(0.03)$ & - \\
\hline
\end{tabular}

${ }^{1} \mathrm{BCS}$ is body condition score; $\mathrm{NE}_{\mathrm{L}}$ is net energy for lactation; $\mathrm{MP}$ is metabolizable protein; RDP is rumen degradable protein; RUP is rumen undegradable protein; NDF is neutral detergent fiber; ADF is acid detergent fiber; NFC is nonfibrous carbohydrates; DCAD is dietary cation-anion difference (calculated as $[(\mathrm{Na}+\mathrm{K})-(\mathrm{Cl}+\mathrm{S})] .{ }^{2}$ Days in milk while lactating, pregnant while dry. ${ }^{3}$ With conceptus while pregnant. ${ }^{4}$ Values enclosed within brackets are referred to anionic close-up diets. na is "not available". - is "absent".

Both the altered passage and fermentability rates of the feedstuffs contribute to altering the fermentation patterns along with the GIT of transition cows, leading to physiological alterations in $\mathrm{pH}$. For example, a transient decrease of rumen $\mathrm{pH}$ could be expected in 
dairy cows coming from the dry period that are suddenly fed a high starch ration in early lactation $[68,69]$. Such changes affect the microbiota composition and the epithelial conformation of transition cows GIT [70-72]. The strict dependence of the height, surface, and rate of absorption of both rumen papillae and gut microvilli on the severity of the diet changes occurring during the transition to calving has been well established [73]. Furthermore, a relationship between changes in peripartum diet in affecting the interaction between GIT epithelial cells and immune system has been recently hypothesized [74]. Recent studies have demonstrated that dietary changes occurring after calving affect rumen bacteria and rumen metabolites through decreasing the rumen $\mathrm{pH}$. These modifications alter rumen milieu permeability, allowing LPS translocation in blood and likely boosting systemic inflammatory responses and leukocytes infiltration in the rumen [75,76]. Furthermore, dietary-driven changes in the rumen $\mathrm{pH}$ and bacterial community interplay with rumen epithelial cells, that regulate the infiltration of several immune mediators in the rumen through saliva [31]. These immune mediators are known to play a pivotal role in the interactions between rumen bacterial populations, forestomach epithelium, and host immune system $[77,78]$. This introduces a new perspective on the role of dietary changes occurring during the peripartum phase in modulating the immune function of dairy cows.

\subsection{Heat Stress Could Boost the Severity of Systemic Inflammation}

In dairy cows, heat stress induces severe milk yield losses and DMI reductions. Recent studies have quantified that reduced energy availability driven by lower feed consumption accounts for only $50 \%$ of milk yield losses registered during heat stress [79]. Furthermore, heat-stressed cows have greater body weight losses, higher plasma cortisol and insulin concentrations, and lower plasma NEFA compared with thermoneutral-raised animals, suggesting that heat stress induces an insulin resistance state [80]. Recently, a common denominator for metabolic effects caused by heat stress in dairy cows has been found in a systemic activation of the immune system. Rhoads et al [81] used studies performed on swine models to hypothesize that the hypoxic state affecting enterocytes during heat stress could induce "leaky gut", allowing LPS translocation into blood. Results obtained in swine models showed blood LPS concentrations to increase six hours after a heat stress exposure, triggering a massive immune response (i.e., increased plasma LPS-binding protein and serum amyloid alpha concentrations) $[82,83]$. Although this mechanism has not been demonstrated to occur in dairy cows under heat stress conditions, it seems probable to indicate LPS translocation at the gut level as the most likely mechanism driving a systemic activation of the immune system. Recent evidence obtained in dairy cows demonstrates that heat stress occurring at any time during the dry period has profound effects on cows during the pre- and postpartum periods and could compromise their performance even after calving [84-87]. In addition to acting as a probable cause for systemic inflammatory events, heat stress during the dry period impairs mammary gland development before calving, metabolism in early lactation, and milk production in the subsequent lactation. Moreover, maternal heat stress in late gestation also negatively affects placental development, fetal growth, and immune competence of the offspring. These results suggest that heat stresses occurring during the peripartum phase of dairy cows present an additional challenge to the metabolism and immune system of the animals while they are approaching the new lactation.

\section{How to Manage a "Good" Transition Period}

State the multifactorial etiology of immune dysfunctions and metabolic challenges concurring in impairing dairy cows adaptation to the new lactation $[1,7,16]$, a key aspect of transition management is to avoid stressful conditions. Thus, the best strategy to ensure a "good transition" in dairy herds consists of a holistic approach. This approach should include management practices aimed at optimizing the welfare condition of the animals, nutritional aspects and specific treatments aimed at modulating metabolic processes that are more likely to exceed the control of homeorhetic mechanisms. Furthermore, it should 
consider the adoption of predictive markers aimed at preventing pathological conditions and genetic selection criteria aimed at increasing animals' resilience.

\subsection{Management Strategies and Facilities to Optimize Animal Welfare}

Typically, transition cows flow successively into four pens: dry, prefresh, maternity, and fresh [88]. Cows should enter the prefresh pen 21 days before expected parturition. Then, cows should be moved to the contiguous maternity pen, where they should stay alone for no longer than three days to avoid any distress from prolonged isolation. Finally, cows should be moved to the fresh pen, where they should stay for approximately 21-30 days postpartum, allowing closer monitoring and perhaps being fed a different diet from lactating cows (see Table 1).

In all transition pens, a soft and comfortable lying surface and adequate ventilation should be provided (i.e., dry and deep layer of shavings, straw, or sand as bedding material and a minimum airspeed of $1 \mathrm{~m} \mathrm{~s}^{-1}$ ), as well as feed bunks with headlocks (76 cm wide) these are preferred to post-and-rail design [89-94]. These requirements are essential as is the need for frequent caregiver examinations (keeping in mind that lockup time should be as short as possible). They also mitigate competition while feeding, providing subordinate cows a certain level of protection [95]. Overstocking should be minimized to ensure sufficient bunk and resting space (i.e., at least $13 \mathrm{~m}^{2}$ per cow). Thus, each pen should be sized using $120-150 \%$ average calving rate (depending on average stay of the animals in each pen) to avoid overstocking when calving rate is higher [88]. Grouping strategies should be planned carefully to avoid pointless movements that can lead to social stressors. Regrouping or inclusion of new animals requires the stabilization of social hierarchy, increasing agonistic and competitive behaviors [42,54,55]; these social interactions can have detrimental effects during the days closer to calving (i.e., reducing feed and water intake, increasing standing time and decreasing lying time) [28]. Furthermore, separating primiparous cows from the herd during their first pregnancy and lactation should be considered in large dairy farms, as these animals are more susceptible to adverse effects resulting from social interactions with dominant subjects [96,97].

Dry and prefresh pens can have either freestall or loose bedded pack layout. Maternity pens should guarantee the expression of innate maternal behavior through ensuring calm parturition in an appropriate environment, minimizing disturbances and risk of mistaken identity of the offspring [98]. Good results can be obtained both with individual and group pens, separated from the rest of the herd. Maternity pens should be designed to ensure adequate space ( $>13 \mathrm{~m}^{2}$ per cow), a soft and clean surface (deep straw bedding is preferred), easy access, proximity to prefresh area, and options for hiding (i.e., a plywood barrier covering half of the pen) $[99,100]$. A series of papers $[30,32,101]$ demonstrated that providing the maternity pen with additional space and a physical blind (created using plastic road barriers and plywood, a steel gate, and shade cloth) may benefit periparturient cows and heifers, facilitating natural calving behaviors and reducing inflammation before calving.

Immediately after calving, the calf is usually separated from the dam, although public concern about this practice is increasing [102]. As reviewed by Johnsen et al. [84] different dam rearing systems that maintain cow-calf contact for longer can be a viable option even in modern dairy farms, ensuring special attention is provided to hygiene and the control of transmissible diseases.

\subsection{Nutritional Strategies and Modulatory Treatments to Improve the Adaptation of Dairy Cows} to the New Lactation

Considerable literature exists on the best diet formulation strategies for dairy cows during the initial dry period, and subsequent new lactation $[20,103,104]$. These strategies focus on satisfying nutrient requirements avoiding metabolic challenges driven by sudden changes in diet composition. Furthermore, there is a growing interest regarding the inclusion of nutraceuticals on the diet of transition dairy cows due to their specificity in modulating metabolic pathways (i.e., energy metabolism and the immune functions), allowing a fine tuning on the metabolic processes that are more likely to exceed the control 
of homeorhetic mechanisms [105,106]. These compounds include probiotics, prebiotics, dietary lipids, functional peptides, phytoextracts, microminerals, vitamins, and methyl donors. However, the requirement of dairy cows for most of these active principles is very low and their direct dietary inclusion is hard to fit with the feeding routine adopted in most commercial dairy farms. Furthermore, each active principle mentioned above affects few metabolic pathways through a highly specific mode of action, while molecules interacting with multiple body compartments could likely provide a greater benefit against the multifactorial challenges affecting the metabolism of transition dairy cows. Thus, several commercial products containing a mixture of active substances have been developed to address these limitations, allowing direct dietary inclusion at the farm level. For example, Omnigen-AF (OAF) is known as an immune modulator that could be included in the diet of dairy cows from dry-off to the first month of lactation, providing positive effects on leukocyte function and a consequent reduction of the incidence of infectious diseases in TP $[24,107]$. Although a direct effect of OAF on the gene expression of neutrophils has been reported [108], a recent study found no effects on neutrophils diapedesis measured in-vivo or on the amelioration of liver metabolism and inflammation of dairy cows receiving the feed additive $[48,109]$. Nevertheless, the same study described dairy cows receiving OAF to have an increased abundance of lymphocytes at the blood level and improved leukocyte function after ex-vivo stimulation with LPS (lower lactate production and lower glucose consumption). These outcomes, paired with the improved rumination time and energy metabolism found in dairy cows receiving the additive, suggest that OAF has an indirect effect on immune function, likely mediated by positive effects on energy metabolism and feeding behavior.

Besides nutritional aspects related to diet formulation, recent interest in the alterations occurring in the immune functions of dairy cows during the peripartum period have promoted the development of specific treatments aimed at reducing their negative effects. Pegbovigrastim (Imrestor; Elanco Animal Health Greenfield, IL, USA) is a commercial product consisting of pegylated recombinant bovine granulocytes-colony stimulating factor (PEG-rbG-CSF), aimed at stimulating the circulating numbers, and possibly function of neutrophils. G-CSF is a cytokine that induces a state of neutrophilia, characterized by a 'left-shift' towards progenitor cells with a release of mature neutrophils and band cells from storage pools in bone marrow [110]. PEG-rbG-CSF only needs to be injected two times (a $15 \mathrm{mg}$ injection approximately a week before parturition and a second injection within $24 \mathrm{~h}$ after parturition), addressing the limitations of rbG-CSF treatment (i.e., daily injections, leading to an impractical on-farm application). Some studies using this product have demonstrated substantial increases in circulating neutrophil, monocyte, and eosinophil counts for several weeks $[35,94,111-114]$. These were paired with modest increases in per-cell function, most consistently of extracellular release of myeloperoxidase [112,115]. From a molecular perspective, the abundance of mRNA in most genes involved in the cell adhesion (ITGB2, ITGAL, TLN1, SELL, SELPLG, and CD44), recognition and immune stimulation (CD14, CD16, MYD88, TLR2, and TLR4), antimicrobial activity (MMP9, LTF, and LCN2), and inflammation cascade (CASP1, TNFRSF1A, IL1B, IL1R, IL18, IRAK1, NLRP3, and $S 100 A 8$ ), together with the expression of SOD2 and ALOX5, increased in whole blood leukocytes from dairy cows treated with PEG-rbG-CSF during the TP [35,111]. Conversely, treated cows showed lower expression of RPL13A, ALOX15, IL8, and TNF. In another study, isolated neutrophils from the blood of cows receiving PEG-rbG-CSF had an increased expression of genes related to the chain of functional steps (ICAM1, TLR2 and PTGS2), while those isolated from the uterus at 4 and 7 days postpartum showed 11 differentially expressed genes, which collectively suggested enhanced antimicrobial capacity [116]. Despite occurring only at the transcriptional level, these differences in gene expression suggest a possible improvement of migration, adhesion, and antimicrobial ability, and enhanced inflammatory response of leukocytes (especially neutrophils) with PEG-rbG-CSF. In turn, this could trigger immune cell activation and enhanced function allowing a complete activation of the immune machinery against the challenges occurring in post-partum. Recently, 
Lopreiato et al. [14] showed, for the first time, the effect of PEG-rbG-CSF in maintaining stable (with no drops) PIC levels during the first month after parturition. This reflects greater regulation of neutrophil recruitment, tracking, and maturation during the inflammatory response, providing evidence of the immunomodulatory action of PEG-rbG-CSF around parturition, when dairy cows are highly immune hypo-reactive. Several randomized controlled trials have demonstrated an approximately one-third relative reduction in the incidence of clinical mastitis in early lactation following treatment with PEG-rbGCSF $[115,117,118]$. Conversely, two studies reported no differences in the incidence risk for retained placenta $[113,115]$, and one study reported PEG-rbG-CSF to increase the incidence risk of metritis at 21 days postpartum [115]. Taken together, these results suggest that PEG-rbG-CSF do not consistently lead to a reduction in the incidence of diseases thought to be related to neutrophil function(i.e., retained placenta, metritis, and endometritis) [119], suggesting that a massive increase in the number of neutrophils available in circulation does not correspond to fewer diseases.

Finally, treatments that are classically adopted in transition cows to modulate rumen fermentation, recently revealed to have a potential role in mitigating the immune dysfunction occurring immediately before and after parturition. Monensin is known for its effect on rumen bacteria populations, resulting in increased propionic acid and reduced lactic acid and methane production $[67,120,121]$. Thus, modulation of rumen fermentation through monensin is an effective strategy to address the risk of both ketosis and acidosis in dairy cows at the onset of lactation [122]. These positive effect of monensin on rumen fermentation is reflected by trends of several plasma analytes (i.e reduced BHB and NEFA concentrations and higher plasma glucose) in cows treated with monensin $[120,121,123]$. A recent study [124,125] found reduced infiltration of $\mathrm{T}$ and $\mathrm{B}$ leukocytes in the rumen fluid from transition dairy cows that received a controlled-release capsule of monensin 21 days before the expected calving date (expected release rate, $335 \mathrm{mg} / \mathrm{d}$ for 95 days). Such an outcome suggests monensin promotes the stabilization of rumen milieu, probably through mitigating $\mathrm{pH}$ alterations related to the adaptation of dairy cows to the lactation diet. This provides a new perspective on the utilization of ionophores to modulate the immune system of early lactating cows.

\subsection{Early Detection of Risky Animals through Plasma Analytes Trends and Behavioral Patterns}

Several studies have been performed on biological fluids of transitioning dairy cows (i.e., urine, blood, saliva, rumen fluid) using different analytical procedures. Research efforts have focused on identifying candidate biomarkers that might reflect 'at risk' condition for developing early lactation diseases (i.e., ketosis, mastitis, metritis, lameness, retained placenta, and milk fever) [126-128]. Considering the extent of this topic, this review will be only focused on predictive markers allowing a close monitoring of the immune status of dairy cows that are approaching to calving. Plasma analytes reflecting metabolic and immune conditions represent a promising tool in this respect $[13,129,130]$. Besides considering single analytes as biomarkers for specific metabolic patterns of dairy cows, a valuable strategy could be the calculation of indexes aggregating trends of multiple plasma analytes detected at specific time points relative to the calving date. Several promising indexes have been developed on postpartal trends of plasma analytes reflecting liver function and the acute phase response. Bertoni et al. [8] calculated the liver activity index (LAI) by aggregating the albumin, cholesterol, and retinol concentrations measured 5, 15, and 30 days after calving. Similarly, Trevisi et al. [131] calculated the liver functionality index (LFI) aggregating the albumin, cholesterol, and bilirubin concentrations measured 3 and 28 days after calving. Retrospectively dividing a group of transition dairy cows based on their liver condition (as reflected by these indexes), three studies $[19,132,133]$ consistently found animals with the lowest LAI or LFI values to have the most severe inflammatory condition in early lactation (i.e., higher PICs and oxidant species concentrations in blood and higher SCC in milk). Furthermore, animals with the lowest LAI or LFI values had the lowest milk yield, worst reproductive performances, and greatest disease incidence 
in early lactation. This suggests LAI and LFI calculations are valuable tools for following up the adaptation of dairy cows to the new lactation $[15,134]$. Recent research by the same group [135] provided new perspectives on the use of blood indexes as predictive biomarkers as they found the plasma AGR of late lactating cows to reflect their adaptation to subsequent calving and lactation.

Other promising predictive indicators include those related to the animal's behavior, such as rumination, activity, and lying times. The availability of sensors automatically monitoring these behavioral measures allows the detection of alterations that might reflect illness or disease risk in an animal $[81,136,137]$. Chewing and rumination times are affected by several factors [138], and their trends around calving reflect the likelihood of dairy cows developing severe inflammatory conditions or diseases in early lactation [139-141]. Cows with reduced rumination time before calving are known to maintain this even after calving, and these animals are more likely to develop health disorders during the peripartum phase (i.e., metabolic and digestive disorders and severe cases of mastitis and metritis) compared to cows with a greater rumination time ante-partum [140,142]. Recently, Abuelo et al. [1] extended such a relationship way beyond the TP, demonstrating that cows with the greatest reduction of rumination time at dry-off were more likely to develop ketosis or lameness in early lactation. Moreover, peripartum trends of plasma analytes from cows with a reduced rumination time during the first few days of lactation typically reflect a more marked inflammatory condition compared with those from cows having high rumination time at the onset of lactation $[140,141]$. This suggests that the occurrence of severe inflammation around parturition is associated with a slower increase of rumination time after calving. Ref. [142] have found that cows undergoing a subclinical rumen acidosis condition (as reflected by the increased VFAs content, altered acetate to propionate ratio and decreased $\mathrm{pH}$ of the rumen fluid) spent a similar amount of time ruminating during the day as compared to healthy animals, but their RT differed after the morning feeding. Besides rumination time, time spent lying can predict the onset of several diseases, although this relationship has not been fully elucidated. Itle et al. [77] reported clinically ketotic cows to have a reduced lying time in the week preceding calving. Conversely, Rodriguez-Jimenez et al. [138] hypothesized that longer lying time (and reduced standing time) during the days leading to parturition could predispose dairy cows to postpartal ketosis through reducing DMI. Such a hypothesis is supported by the positive relationship between lying time, changes in plasma NEFA concentration, and the risk of developing ketosis (alone or paired with other diseases) detected by others during the first weeks of lactation $[143,144]$. In a recent paper on multiparous cows, Cattaneo et al. [23] reported cows developing retained placenta to have increased lying time during the last 3 weeks before calving, but no alterations in prepartal lying time were found for cows developing metritis. Conversely, Neave et al. [118] found that cows later diagnosed with metritis had reduced lying time and fewer lying bouts before calving, while Barragan et al. [3] detected an opposite trend in prepartal lying time for primiparous and no differences for multiparous cows developing metritis.

\subsection{Genomic Information to Prevent Metabolic Dysfunctions}

As TP severely challenges the metabolism and immunity of dairy cows, breeding cattle displaying lower susceptibility to disturbances could be a key step towards establishing resilient animal production systems [145]. The existence of genetic differences in dairy cattle to common health disorders was investigated and confirmed over the years [131]. Consequently, a growing interest in including health-related traits in genetic selection programs led to the concept of a comprehensive diseases prevention strategy, accounting also for genetic information $[38,146,147]$. The feasibility of such kind of breeding program has been reported by scientific literature $[148,149]$ and implemented with the introduction of the genomic prediction Wellness Trait Index [150], which includes six disease resistance traits (mastitis, metritis, ketosis, retained placenta, displaced abomasum and lameness) in estimating differences in expected lifetime profit. Moreover, in 2018, the US genetic 
selection index $(\mathrm{NM} \$ 18)$ was updated with the insertion of the Health Trait Subindex, which accounted for six disease resistance traits (milk fever, displaced abomasum, ketosis, mastitis, metritis and retained placenta) [151].

A feasible solution to improve the efficiency of current breeding programs at preventing transition cows diseases could be understanding the genetic architecture of specific biomarkers related to metabolism, immune system, and inflammation. Indeed, the genomic prediction quality of a model strictly depends on the trait's genetic architecture [152,153], and a control exerted by a large number of genes with small additive effect (polygenic control) is often to take into account when dealing with complex traits-such as health-related ones-[154]. Thus, identifying some intermediate phenotypes (or "endophenotypes"), which are measurable markers correlated to an illness-expected to be characterized by a simpler genetic control than the end-point phenotype-could improve our power in detecting candidate genes underlying the resistance to a disease $[108,155,156]$.

In this respect, increased evidence of the role of genotype in modulating the inflammation process (mostly related to APOE genes) has already been reported in murine models $[157,158]$. Significant associations between genetic variants expressing different levels of inflammatory biomarkers and the occurrence of several diseases have been well investigated in human medicine $[108,159,160]$. Thus, identifying similar associations in the genome of dairy cows has the potential to drive breeding programs aiming to improve the effectiveness of animal responses to physiological and environmental stressors [161]. This represents a promising solution against the metabolic challenges occurring during the TP.

Recently, the genetic structure of several blood, hair, and milk biomarkers related to metabolism, immunity, inflammation, and oxidative stress response in Holstein and Simmental cows has been investigated [162]. Specific and precise genomic regions were identified to be associated with three biomarkers levels, namely serum gamma-glutamyl transferase, paraoxonase and ceruloplasmin, all involved in anti-oxidant functions. Moreover, paraoxonase and ceruloplasmin are considered biomarkers of inflammation, as they are involved in the acute phase response as negative and positive acute phase proteins, respectively [15]. Interestingly, the identified genomic regions included the genes that directly code for each protein (GGT1 and GGT5 genes on chromosome 17 for gammaglutamyl transferase, $\mathrm{PON} 1$ on chromosome 4 for paraoxonase and $\mathrm{CP}$ on chromosome 1 for ceruloplasmin), suggesting cis-regulation. Candidate causative variants were identified but are not yet validated.

Genetic resistance to ketosis and NEB-related diseases has already been explored and promising results have been obtained in dairy cows. RNA-seq studies performed on dairy cows undergoing different degrees of NEB have revealed that genes involved in fat metabolism have the greatest differences in transcription levels [163]. Although transcriptional and post-transcriptional regulation of gene expression do not relate differences in RNA transcripts found in this study to differences at the genotype level, energy metabolism genes were selected as suitable targets for genetic selection in subsequent years. Polymorphisms on the gene encoding for apolipoprotein B receptor (APOBR gene on chromosome 25) have been suggested to affect the likelihood of Holstein cows developing ketosis [164,165]. Accordingly, that gene was found to be significantly associated with glycerophosphocholine-phosphocholine ratio in milk, which was previously proposed as a ketosis biomarker [166]. It was suggested that cows with a high glycerophosphocholinephosphocholine ratio were disposed to a greater ability in utilizing blood phosphatidylcholine as a source for milk fat synthesis. This likely reflects their lower susceptibility to developing severe lipomobilization processes that precede ketosis status. APOBR gene was suggested as promising candidate gene associated with metabolic status of dairy cattle also by Huang and colleagues [167]. In this study a genome wide association study (GWAS) on ketosis resistance in Chinese Holstein cattle was performed, finding out that genes explaining largest variance portions were all involved in either insulin or lipid metabolism. Several other SNPs and genes mostly located on chromosomes 6, 14, and 20 were found to have a significant genetic association with milk BHB concentration in dairy cows [168]. 
In particular, five genes (HSD17B10 and HTR2 on chromosome X; ABCA1 and ABCA2 on chromosome 8; LIPC on chromosome 10) were found to be positively related to the longitudinal concentration of BHB in Holstein milk [169].

Finally, further research is related to the resistance of infectious diseases, as the TP alters immuno-competences. A genetic effect on this phenotype was demonstrated in Canadian Holstein cattle [170] and subsequent studies focused on resistance to specific diseases, such as Bovine Respiratory Disease (BRD), tuberculosis and mastitis (reviewed in Raszek et al. [134]).

To conclude, genomics is helping in adding valuable information to the development of an efficient health management system. Each disease is characterized by a specific genetic architecture and correlations with other traits which should be properly investigated; independent functional validation of candidate causative variants is also crucial for the implementation of breeding programs. Finally, additional efforts in improving current disease recoding systems are required to ensure an easier estimation of genetic prediction.

\section{Conclusions}

Recent advances in molecular biology and genomics provide greater understanding of the alterations occurring in the metabolism, immune system functioning, and gene expression regulation of dairy cows that are approaching calving, and the linkages between these. Such advances allow for a wider perspective on the mechanisms driving the cow's adaptation to parturition as well as greater understanding of the etiology of early lactation diseases. These new perspectives challenge the "classical" definition of TP, driving researchers and dairy farmers to extend their focus to a wider time frame (even preceding the dry-off day) to successfully identify animals that are most likely to undergo poor adaptation to the new lactation. The best approach to manage a "good transition" relies on ensuring optimal welfare conditions and balanced diets for the whole herd, to minimize distressing events that could accrue the metabolic challenges around calving. This general principle could be combined with the adoption of prognostic indicators to detect risky subjects, allowing early intervention through specific treatments aimed at minimizing the stressing conditions occurring around calving. In the near future, the interest of genomics on the genetic asset behind the adaptation of dairy cows to early lactation challenges could provide more resilient animals through specialized genetic breeding programs. Despite these encouraging perspectives on transition period management, it is clear that our understanding of physiological processes occurring in dairy cows' metabolism during this crucial phase of the lactation cycle requires further investigation. Therefore, the TP (likely extended from dry-off) remains "the final frontier" for research in dairy sciences.

Author Contributions: Conceptualization, M.M., L.C., M.M.P. and V.L.; investigation, M.M., L.C., M.M.P. and V.L.; writing—original draft preparation, M.M., L.C., M.M.P. and V.L.; writing-review and editing, A.M. and E.T.; visualization, A.M. and E.T.; supervision, A.M. and E.T. All authors have read and agreed to the published version of the manuscript.

Funding: Research in the Department of Animal Sciences, Food and Nutrition is supported in part by CREI (Romeo and Enrica Invernizzi Research Center of the Università Cattolica del S. Cuore funded by the "Fondazione Romeo ed Enrica Invernizzi", Milan, Italy) and in part by the Lombardy Region (D.d.s. 21.12.2018 n. 19442, Project RABoLa).

Institutional Review Board Statement: Not applicable.

Informed Consent Statement: Not applicable.

Data Availability Statement: Not applicable.

Conflicts of Interest: The authors declare no conflict of interest. 


\section{References}

1. Abuelo, A.; Wisnieski, L.; Brown, J.L.; Sordillo, L.M. Rumination time around dry-off relative to the development of diseases in early-lactation cows. J. Dairy Sci. 2021, 104, 5909-5920. [CrossRef] [PubMed]

2. Akbar, H.; Batistel, F.; Drackley, J.K.; Loor, J.J. Alterations in Hepatic FGF21, Co-Regulated Genes, and Upstream Metabolic Genes in Response to Nutrition, Ketosis and Inflammation in Peripartal Holstein Cows. PLoS ONE 2015, 10, e0139963. [CrossRef] [PubMed]

3. Barragan, A.A.; Piñeiro, J.M.; Schuenemann, G.M.; Rajala-Schultz, P.J.; Sanders, D.E.; Lakritz, J.; Bas, S. Assessment of daily activity patterns and biomarkers of pain, inflammation, and stress in lactating dairy cows diagnosed with clinical metritis. J. Dairy Sci. 2018, 101, 8248-8258. [CrossRef]

4. Batistel, F.; Arroyo, J.M.; Garces, C.; Trevisi, E.; Parys, C.; Ballou, M.; Cardoso, F.; Loor, J. Ethyl-cellulose rumen-protected methionine alleviates inflammation and oxidative stress and improves neutrophil function during the periparturient period and early lactation in Holstein dairy cows. J. Dairy Sci. 2018, 101, 480-490. [CrossRef] [PubMed]

5. Beauchemin, K. Invited review: Current perspectives on eating and rumination activity in dairy cows. J. Dairy Sci. 2018, 101, 4762-4784. [CrossRef] [PubMed]

6. $\quad$ Berghof, T.V.L.; Poppe, M.; Mulder, H. Opportunities to Improve Resilience in Animal Breeding Programs. Front. Genet. 2019, 9 692. [CrossRef]

7. Bertoni, G.; Trevisi, E. Use of the Liver Activity Index and Other Metabolic Variables in the Assessment of Metabolic Health in Dairy Herds. Vet. Clin. N. Am. Food Anim. Pract. 2013, 29, 413-431. [CrossRef] [PubMed]

8. Bertoni, G.; Trevisi, E.; Han, X.; Bionaz, M. Effects of Inflammatory Conditions on Liver Activity in Puerperium Period and Consequences for Performance in Dairy Cows. J. Dairy Sci. 2008, 91, 3300-3310. [CrossRef] [PubMed]

9. McCabe, C.J.; Boerman, J.P. Invited Review: Quantifying protein mobilization in dairy cows during the transition period. Appl. Anim. Sci. 2020, 36, 389-396. [CrossRef]

10. Bertoni, G.; Trevisi, E.; Houdijk, J.; Calamari, L.; Athanasiadou, S. Welfare Is Affected by Nutrition through Health (Immune Function and Inflammation); Phillips, C.J.C., Ed.; Springer International Publishing: Cham, Switzerland, 2016.

11. Bertoni, G.; Trevisi, E.; Lombardelli, R. Some new aspects of nutrition, health conditions and fertility of intensively reared dairy cows. Ital. J. Anim. Sci. 2009, 8, 491-518. [CrossRef]

12. Bertulat, S.; Fischer-Tenhagen, C.; Suthar, V.; Möstl, E.; Isaka, N.; Heuwieser, W. Measurement of fecal glucocorticoid metabolites and evaluation of udder characteristics to estimate stress after sudden dry-off in dairy cows with different milk yields. J. Dairy Sci. 2013, 96, 3774-3787. [CrossRef] [PubMed]

13. Biswas, S.K.; Lopez-Collazo, E. Endotoxin tolerance: New mechanisms, molecules and clinical significance. Trends Immunol. 2009, 30, 475-487. [CrossRef] [PubMed]

14. Lopreiato, V.; Minuti, A.; Trimboli, F.; Britti, D.; Morittu, V.; Cappelli, F.P.; Loor, J.; Trevisi, E. Immunometabolic status and productive performance differences between periparturient Simmental and Holstein dairy cows in response to pegbovigrastim. J. Dairy Sci. 2019, 102, 9312-9327. [CrossRef]

15. Bomba, L.; Nicolazzi, E.L.; Milanesi, M.; Negrini, R.; Mancini, G.; Biscarini, F.; Stella, A.; Valentini, A.; Ajmone-Marsan, P. Relative extended haplotype homozygosity signals across breeds reveal dairy and beef specific signatures of selection. Genet. Sel. Evol. 2015, 47, 25. [CrossRef] [PubMed]

16. Borchers, M.; Chang, Y.; Tsai, I.; Wadsworth, B.; Bewley, J. A validation of technologies monitoring dairy cow feeding, ruminating and lying behaviors. J. Dairy Sci. 2016, 99, 7458-7466. [CrossRef] [PubMed]

17. Bradford, B.J.; Swartz, T. Review: Following the smoke signals: Inflammatory signaling in metabolic homeostasis and homeorhesis in dairy cattle. Animal 2020, 14, s144-s154. [CrossRef]

18. Butler, W.R. Nutrition, negative energy balance and fertility in the postpartum dairy cow. Cattle Pract. 2005, 13, 13-18.

19. Calamari, L.; Soriani, N.; Panella, G.; Petrera, F.; Minuti, A.; Trevisi, E. Rumination time around calving: An early signal to detect cows at greater risk of disease. J. Dairy Sci. 2014, 97, 3635-3647. [CrossRef]

20. Campler, M.; Munksgaard, L.; Jensen, M.B.; Weary, D.; Von Keyserlingk, M. Short communication: Flooring preferences of dairy cows at calving. J. Dairy Sci. 2014, 97, 892-896. [CrossRef]

21. Canning, P.; Hassfurther, R.; Terhune, T.; Rogers, K.; Abbott, S.; Kolb, D. Efficacy and clinical safety of pegbovigrastim for preventing naturally occurring clinical mastitis in periparturient primiparous and multiparous cows on US commercial dairies. J. Dairy Sci. 2017, 100, 6504-6515. [CrossRef] [PubMed]

22. Cattaneo, L.; Lopreiato, V.; Piccioli-Cappelli, F.; Trevisi, E.; Minuti, A. Plasma albumin-to-globulin ratio before dry-off as a possible index of inflammatory status and performance in the subsequent lactation in dairy cows. J. Dairy Sci. 2021, 104, 8228-8242. [CrossRef]

23. Cattaneo, L.; Lopreiato, V.; Trevisi, E.; Minuti, A. Association of postpartum uterine diseases with lying time and metabolic profiles of multiparous Holstein dairy cows in the transition period. Vet. J. 2020, 263, 105533. [CrossRef] [PubMed]

24. Mezzetti, M.; Minuti, A.; Piccioli-Cappelli, F.; Amadori, M.; Bionaz, M.; Trevisi, E. The role of altered immune function during the dry period in promoting the development of subclinical ketosis in early lactation. J. Dairy Sci. 2019, 102, 9241-9258. [CrossRef] [PubMed]

25. Choi, S.H.; Chung, S.S.; Park, K.S. Re-highlighting the action of PPAR $\gamma$ in treating metabolic diseases. F1000Research 2018, 7, 1127. [CrossRef] [PubMed] 
26. Celi, P. Oxidative Stress in Ruminants; Mandelker, L., Vajdovich, P., Eds.; Humana Press: Totowa, NJ, USA, 2011.

27. Cole, J.; VanRaden, P.; O'Connell, J.; Van Tassell, C.; Sonstegard, T.; Schnabel, R.; Taylor, J.; Wiggans, G. Distribution and location of genetic effects for dairy traits. J. Dairy Sci. 2009, 92, 2931-2946. [CrossRef]

28. Cook, N.B. Designing Facilities for the Adult Dairy Cow During the Nonlactation and Early Lactation Period. Vet. Clin. N. Am. Food Anim. Pract. 2019, 35, 125-138. [CrossRef] [PubMed]

29. Cornelius, D.C. Preeclampsia: From Inflammation to Immunoregulation. Clin. Med. Insights Blood Disord. 2018, 11, 1-6. [CrossRef]

30. Creutzinger, K.; Dann, H.; Krawczel, P.; Habing, G.; Proudfoot, K. The effect of stocking density and a blind on the behavior of Holstein dairy cattle in group maternity pens. Part I: Calving location, locomotion, and separation behavior. J. Dairy Sci. 2021, 104, 7109-7121. [CrossRef]

31. Ingvartsen, K.L.; Moyes, K. Nutrition, immune function and health of dairy cattle. Animal 2013, 7, 112-122. [CrossRef]

32. Creutzinger, K.; Dann, H.; Moraes, L.; Krawczel, P.; Proudfoot, K. Effects of prepartum stocking density and a blind on physiological biomarkers, health, and hygiene of transition Holstein dairy cows. J. Dairy Sci. 2021, 104, 886-898. [CrossRef] [PubMed]

33. Sordillo, L. Nutritional strategies to optimize dairy cattle immunity. J. Dairy Sci. 2016, 99, 4967-4982. [CrossRef]

34. Creutzinger, K.C.; Proudfoot, K.L. Invited Review: Design and management of group maternity areas for dairy cows. Appl. Anim. Sci. 2020, 36, 124-132. [CrossRef]

35. Minuti, A.; Bionaz, M.; Lopreiato, V.; Janovick, N.A.; Rodriguez-Zas, S.L.; Drackley, J.K.; Loor, J.J. Prepartum dietary energy intake alters adipose tissue transcriptome profiles during the periparturient period in Holstein dairy cows. J. Anim. Sci. Biotechnol. 2020, 11, 1. [CrossRef]

36. Crookenden, M.; Phyn, C.; Turner, S.; Loor, J.; Smith, A.; Lopreiato, V.; Burke, C.; Heiser, A.; Roche, J. Feeding synthetic zeolite to transition dairy cows alters neutrophil gene expression. J. Dairy Sci. 2020, 103, 723-736. [CrossRef] [PubMed]

37. Dahl, G.E.; Tao, S.; LaPorta, J. Heat Stress Impacts Immune Status in Cows Across the Life Cycle. Front. Vet. Sci. 2020, 7, 116. [CrossRef] [PubMed]

38. Trevisi, E.; Jahan, N.; Bertoni, G.; Ferrari, A.; Minuti, A. Pro-Inflammatory Cytokine Profile in Dairy Cows: Consequences for New Lactation. Ital. J. Anim. Sci. 2015, 14, 285-292. [CrossRef]

39. Dieho, K.; Bannink, A.; Geurts, I.; Schonewille, J.; Gort, G.; Dijkstra, J. Morphological adaptation of rumen papillae during the dry period and early lactation as affected by rate of increase of concentrate allowance. J. Dairy Sci. 2016, 99, 2339-2352. [CrossRef] [PubMed]

40. Dijkstra, J.; Ellis, J.; Kebreab, E.; Strathe, A.; Lopez, S.; France, J.; Bannink, A. Ruminal pH regulation and nutritional consequences of low pH. Anim. Feed Sci. Technol. 2012, 172, 22-33. [CrossRef]

41. Dingwell, R.T.; Kelton, D.F.; Leslie, K.E.; Edge, V.L. Deciding to dry-off: Does level of production matter? In National Mastitis Council Annual Meeting Proceedings; National Mastitis Council, Inc.: Madison, WI, USA, 2001; pp. 69-79.

42. Van Dorland, H.A.; Richter, S.; Morel, I.; Doherr, M.G.; Castro, N.; Bruckmaier, R.M. Variation in hepatic regulation of metabolism during the dry period and in early lactation in dairy cows. J. Dairy Sci. 2009, 92, 1924-1940. [CrossRef]

43. Mezzetti, M.; Minuti, A.; Piccioli-Cappelli, F.; Trevisi, E. Inflammatory status and metabolic changes at dry-off in high-yield dairy cows. Ital. J. Anim. Sci. 2019, 19, 51-65. [CrossRef]

44. Dose, J.; Huebbe, P.; Nebel, A.; Rimbach, G. APOE genotype and stress response-A mini review. Lipids Health Dis. 2016, 15, 121. [CrossRef] [PubMed]

45. Douglas, G.; Overton, T.; Bateman, H.; Dann, H.; Drackley, J. Prepartal Plane of Nutrition, Regardless of Dietary Energy Source, Affects Periparturient Metabolism and Dry Matter Intake in Holstein Cows. J. Dairy Sci. 2006, 89, 2141-2157. [CrossRef]

46. Drackley, J.K. Biology of Dairy Cows During the Transition Period: The Final Frontier? J. Dairy Sci. 1999, 82, 2259-2273. [CrossRef]

47. Drackley, J.K.; Dann, H.M.; Douglas, N.; Guretzky, N.A.J.; Litherland, N.B.; Underwood, J.P.; Loor, J.J.; Douglas, G.N. Physiological and pathological adaptations in dairy cows that may increase susceptibility to periparturient diseases and disorders. Ital. J. Anim. Sci. 2005, 4, 323-344. [CrossRef]

48. Milanesi, M.; Passamonti, M.; Cappelli, K.; Minuti, A.; Palombo, V.; Sgorlon, S.; Capomaccio, S.; D’Andrea, M.; Trevisi, E.; Stefanon, B.; et al. Genetic Regulation of Biomarkers as Stress Proxies in Dairy Cows. Genes 2021, 12, 534. [CrossRef] [PubMed]

49. Egger, G.; Dixon, J. Obesity and chronic disease: Always offender or often just accomplice? Br. J. Nutr. 2009, 102, 1238-1242. [CrossRef]

50. Esposito, G.; Irons, P.C.; Webb, E.C.; Chapwanya, A. Interactions between negative energy balance, metabolic diseases, uterine health and immune response in transition dairy cows. Anim. Reprod. Sci. 2014, 144, 60-71. [CrossRef] [PubMed]

51. Fabris, T.F.; LaPorta, J.; Skibiel, A.L.; Corra, F.N.; Senn, B.D.; Wohlgemuth, S.E.; Dahl, G.E. Effect of heat stress during early, late, and entire dry period on dairy cattle. J. Dairy Sci. 2019, 102, 5647-5656. [CrossRef]

52. Filipe, J. Ruminal fluids as substrate for investigating production diseases of small and large ruminant species. CAB Rev. Perspect. Agric. Vet. Sci. Nutr. Nat. Resour. 2019, 14, 1-12. [CrossRef]

53. Fiore, E.; Perillo, L.; Gianesella, M.; Giannetto, C.; Giudice, E.; Piccione, G.; Morgante, M. Comparison between two preventive treatments for hyperketonaemia carried out pre-partum: Effects on non-esterified fatty acids, $\beta$-hydroxybutyrate and some biochemical parameters during peripartum and early lactation. J. Dairy Res. 2021, 88, 38-44. [CrossRef]

54. Fregonesi, J.; Tucker, C.; Weary, D. Overstocking Reduces Lying Time in Dairy Cows. J. Dairy Sci. 2007, 90, 3349-3354. [CrossRef] 
55. Schirmann, K.; Chapinal, N.; Weary, D.; Heuwieser, W.; Von Keyserlingk, M. Short-term effects of regrouping on behavior of prepartum dairy cows. J. Dairy Sci. 2011, 94, 2312-2319. [CrossRef] [PubMed]

56. Fregonesi, J.A.; Veira, D.M.; von Keyserlingk, M.A.G.; Weary, D.M. Effects of Bedding Quality on Lying Behavior of Dairy Cows. J. Dairy Sci. 2007, 90, 5468-5472. [CrossRef]

57. Van Gastelen, S.; Westerlaan, B.; Houwers, D.J.; Van Eerdenburg, F.J.C.M. A study on cow comfort and risk for lameness and mastitis in relation to different types of bedding materials. J. Dairy Sci. 2011, 94, 4878-4888. [CrossRef] [PubMed]

58. Glahn, D.C.; Knowles, E.E.; McKay, D.R.; Sprooten, E.; Raventós, H.; Blangero, J.; Gottesman, I.I.; Almasy, L. Arguments for the sake of endophenotypes: Examining common misconceptions about the use of endophenotypes in psychiatric genetics. Am. J. Med. Genet. Part B Neuropsychiatr. Genet. 2014, 165, 122-130. [CrossRef] [PubMed]

59. Goetz, B.; Lefler, J.; Abeyta, M.; Horst, E.; Mayorga, E.; Al-Qaisi, M.; Rodriguez-Jimenez, S.; Martino, C.; Izzo, A.; La, R.; et al. Effects of dietary microbial feed supplement on production efficacy in lactating dairy cows. JDS Commun. 2021, 2, 118-122. [CrossRef]

60. Grummer, R.R.; Mashek, D.; Hayirli, A. Dry matter intake and energy balance in the transition period. Vet. Clin. N. Am. Food Anim. Pract. 2004, 20, 447-470. [CrossRef] [PubMed]

61. Janovick, N.; Drackley, J. Prepartum dietary management of energy intake affects postpartum intake and lactation performance by primiparous and multiparous Holstein cows. J. Dairy Sci. 2010, 93, 3086-3102. [CrossRef] [PubMed]

62. Guarini, A.; Lourenco, D.; Brito, L.; Sargolzaei, M.; Baes, C.; Miglior, F.; Misztal, I.; Schenkel, F. Genetics and genomics of reproductive disorders in Canadian Holstein cattle. J. Dairy Sci. 2019, 102, 1341-1353. [CrossRef] [PubMed]

63. Habel, J.; Sundrum, A. Mismatch of Glucose Allocation between Different Life Functions in the Transition Period of Dairy Cows. Animals 2020, 10, 1028. [CrossRef] [PubMed]

64. Hassfurther, R.L.; Terhune, T.N.; Canning, P.C. Efficacy of polyethylene glycol-conjugated bovine granulocyte colony-stimulating factor for reducing the incidence of naturally occurring clinical mastitis in periparturient dairy cows and heifers. Am. J. Vet. Res. 2015, 76, 231-238. [CrossRef]

65. Hayes, B.J.; Pryce, J.; Chamberlain, A.J.; Bowman, P.J.; Goddard, M.E. Genetic Architecture of Complex Traits and Accuracy of Genomic Prediction: Coat Colour, Milk-Fat Percentage, and Type in Holstein Cattle as Contrasting Model Traits. PLoS Genet. 2010, 6, e1001139. [CrossRef] [PubMed]

66. Hayirli, A.; Grummer, R.; Nordheim, E.; Crump, P. Animal and Dietary Factors Affecting Feed Intake During the Prefresh Transition Period in Holsteins. J. Dairy Sci. 2002, 85, 3430-3443. [CrossRef]

67. NRC. Nutrient Requirement of Dairy Cattle, 7th ed.; National Academies Press: Washington, DC, USA, 2001.

68. Heiser, A.; LeBlanc, S.; McDougall, S. Pegbovigrastim treatment affects gene expression in neutrophils of pasture-fed, periparturient cows. J. Dairy Sci. 2018, 101, 8194-8207. [CrossRef]

69. Shi, W.; Haisan, J.; Inabu, Y.; Sugino, T.; Oba, M. Effects of starch concentration of close-up diets on rumen pH and plasma metabolite responses of dairy cows to grain challenges after calving. J. Dairy Sci. 2020, 103, 11461-11471. [CrossRef] [PubMed]

70. Hendriks, S.; Phyn, C.; Huzzey, J.; Mueller, K.; Turner, S.-A.; Donaghy, D.; Roche, J. Graduate Student Literature Review: Evaluating the appropriate use of wearable accelerometers in research to monitor lying behaviors of dairy cows. J. Dairy Sci. 2020, 103, 12140-12157. [CrossRef] [PubMed]

71. Herdt, T.H. Ruminant Adaptation to Negative Energy Balance. Vet. Clin. N. Am. Food Anim. Pract. 2000, 16, 215-230. [CrossRef]

72. Steele, M.; Schiestel, C.; AlZahal, O.; Dionissopoulos, L.; Laarman, A.; Matthews, J.; McBride, B. The periparturient period is associated with structural and transcriptomic adaptations of rumen papillae in dairy cattle. J. Dairy Sci. 2015, 98, 2583-2595. [CrossRef]

73. Höglund, J.; Rafati, N.; Rask-Andersen, M.; Enroth, S.; Karlsson, T.; Ek, W.E.; Johansson, Å. Improved power and precision with whole genome sequencing data in genome-wide association studies of inflammatory biomarkers. Sci. Rep. 2019, 9, 16844. [CrossRef]

74. Horst, E.; Kvidera, S.; Baumgard, L. Invited review: The influence of immune activation on transition cow health and performance-A critical evaluation of traditional dogmas. J. Dairy Sci. 2021, 104, 8380-8410. [CrossRef] [PubMed]

75. Huang, H.; Cao, J.; Hanif, Q.; Wang, Y.; Yu, Y.; Zhang, S.; Zhang, Y. Genome-wide association study identifies energy metabolism genes for resistance to ketosis in Chinese Holstein cattle. Anim. Genet. 2019, 50, 376-380. [CrossRef] [PubMed]

76. Ingvartsen, K. Feeding- and management-related diseases in the transition cow: Physiological adaptations around calving and strategies to reduce feeding-related diseases. Anim. Feed. Sci. Technol. 2006, 126, 175-213. [CrossRef]

77. Itle, A.; Huzzey, J.; Weary, D.; Von Keyserlingk, M. Clinical ketosis and standing behavior in transition cows. J. Dairy Sci. 2015, 98, 128-134. [CrossRef] [PubMed]

78. Jahan, N.; Minuti, A.; Trevisi, E. Assessment of immune response in periparturient dairy cows using ex vivo whole blood stimulation assay with lipopolysaccharides and carrageenan skin test. Vet. Immunol. Immunopathol. 2015, 165, 119-126. [CrossRef]

79. Jankord, R.; Zhang, R.; Flak, J.N.; Solomon, M.B.; Albertz, J.; Herman, J.P. Stress activation of IL-6 neurons in the hypothalamus. Am. J. Physiol. Integr. Comp. Physiol. 2010, 299, R343-R351. [CrossRef] [PubMed]

80. Janovick Guretzky, N.A.; Dann, H.M.; Bionaz, M.; Trevisi, E.; Bertoni, G.; Drackley, J.K. Evaluation of acute phase reactants and indices of liver function in serum from dairy cows fed different levels on energy prepartum. In Proceedings of the Joint Annual Meeting ADSA, PSA, AMPA, ASAS, San Antonio, TX, USA, 8-12 July 2007; p. 408. 
81. Rhoads, R.P.; Baumgard, L.H.; Suagee, J.K.; Sanders, S.R. Nutritional Interventions to Alleviate the Negative Consequences of Heat Stress. Adv. Nutr. 2013, 4, 267-276. [CrossRef] [PubMed]

82. Joffre, O.; Nolte, M.A.; Spörri, R.; E Sousa, C.R. Inflammatory signals in dendritic cell activation and the induction of adaptive immunity. Immunol. Rev. 2009, 227, 234-247. [CrossRef]

83. Jofre-Monseny, L.; Minihane, A.-M.; Rimbach, G. Impact of apoE genotype on oxidative stress, inflammation and disease risk. Mol. Nutr. Food Res. 2008, 52, 131-145. [CrossRef]

84. Johnsen, J.F.; Zipp, K.A.; Kälber, T.; de Passillé, A.M.; Knierim, U.; Barth, K.; Mejdell, C.M. Is rearing calves with the dam a feasible option for dairy farms?-Current and future research. Appl. Anim. Behav. Sci. 2016, 181, 1-11. [CrossRef]

85. Kaufman, E.; LeBlanc, S.; McBride, B.; Duffield, T.; Devries, T. Short communication: Association of lying behavior and subclinical ketosis in transition dairy cows. J. Dairy Sci. 2016, 99, 7473-7480. [CrossRef]

86. Kehrli, M.; Nonnecke, B.J.; A Roth, J. Alterations in bovine neutrophil function during the periparturient period. Am. J. Vet. Res. 1989, 50, 207-214. [PubMed]

87. Tao, S.; Dahl, G.E. Invited review: Heat stress effects during late gestation on dry cows and their calves. J. Dairy Sci. 2013, 96, 4079-4093. [CrossRef]

88. Von Keyserlingk, M.A.G.; Olenick, D.; Weary, D.M. Acute Behavioral Effects of Regrouping Dairy Cows. J. Dairy Sci. 2008, 91, 1011-1016. [CrossRef] [PubMed]

89. Kimura, K.; Goff, J.P.; Canning, P.; Wang, C.; Roth, J.A. Effect of recombinant bovine granulocyte colony-stimulating factor covalently bound to polyethylene glycol injection on neutrophil number and function in periparturient dairy cows. J. Dairy Sci. 2014, 97, 4842-4851. [CrossRef] [PubMed]

90. Klein, M.; Buttchereit, N.; Miemczyk, S.P.; Immervoll, A.-K.; Louis, C.; Wiedemann, S.; Junge, W.; Thaller, G.; Oefner, P.J.; Gronwald, W. NMR Metabolomic Analysis of Dairy Cows Reveals Milk Glycerophosphocholine to Phosphocholine Ratio as Prognostic Biomarker for Risk of Ketosis. J. Proteome Res. 2011, 11, 1373-1381. [CrossRef] [PubMed]

91. Van Knegsel, A. Metabolic adaptation during early lactation: Key to cow health, longevity and a sustainable dairy production chain. CAB Rev. Perspect. Agric. Vet. Sci. Nutr. Nat. Resour. 2014, 9, 1-15. [CrossRef]

92. König, S.; May, K. Invited review: Phenotyping strategies and quantitative-genetic background of resistance, tolerance and resilience associated traits in dairy cattle. Animal 2019, 13, 897-908. [CrossRef]

93. Kuhla, B. Review: Pro-inflammatory cytokines and hypothalamic inflammation: Implications for insufficient feed intake of transition dairy cows. Animal 2020, 14, s65-s77. [CrossRef] [PubMed]

94. Mondaca, M.R. Ventilation Systems for Adult Dairy Cattle. Vet. Clin. N. Am. Food Anim. Pract. 2019, 35, 139-156. [CrossRef] [PubMed]

95. Yepes, F.A.L.; Nydam, D.V.; Mann, S.; Caixeta, L.; McArt, J.A.A.; Overton, T.R.; Wakshlag, J.J.; Huson, H.J. Longitudinal Phenotypes Improve Genotype Association for Hyperketonemia in Dairy Cattle. Animals 2019, 9, 1059. [CrossRef]

96. LeBlanc, S.J. Reproductive tract inflammatory disease in postpartum dairy cows. Animal 2014, 8, 54-63. [CrossRef]

97. Leroy, J.; Vanholder, T.; Van Knegsel, A.; Garcia-Ispierto, I.; Bols, P. Nutrient Prioritization in Dairy Cows Early Postpartum: Mismatch Between Metabolism and Fertility? Reprod. Domest. Anim. 2008, 43, 96-103. [CrossRef] [PubMed]

98. Liboreiro, D.N.; Machado, K.S.; Silva, P.R.; Maturana, M.M.; Nishimura, T.K.; Brandão, A.P.; Endres, M.I.; Chebel, R.C. Characterization of peripartum rumination and activity of cows diagnosed with metabolic and uterine diseases. J. Dairy Sci. 2015, 98, 6812-6827. [CrossRef] [PubMed]

99. Lopes, F.; Rosa, G.; Pinedo, P.; Santos, J.E.P.; Chebel, R.C.; Galvao, K.N.; Schuenemann, G.M.; Bicalho, R.C.; Gilbert, R.O.; Rodrigez-Zas, S.; et al. Genome-enable prediction for health traits using high-density SNP panel in US Holstein cattle. Anim. Genet. 2020, 51, 192-199. [CrossRef]

100. Lopreiato, V.; Mezzetti, M.; Cattaneo, L.; Ferronato, G.; Minuti, A.; Trevisi, E. Role of nutraceuticals during the transition period of dairy cows: A review. J. Anim. Sci. Biotechnol. 2020, 11, 96. [CrossRef] [PubMed]

101. Creutzinger, K.; Dann, H.; Krawczel, P.; Moraes, L.; Pairis-Garcia, M.; Proudfoot, K. The effect of stocking density and a blind on the behavior of Holstein dairy cows in group maternity pens. Part II: Labor length, lying behavior, and social behavior. J. Dairy Sci. 2021, 104, 7122-7134. [CrossRef]

102. Marras, G.; Gaspa, G.; Sorbolini, S.; Dimauro, C.; Marsan, P.A.; Valentini, A.; Williams, J.; Macciotta, N.P.P. Analysis of runs of homozygosity and their relationship with inbreeding in five cattle breeds farmed in Italy. Anim. Genet. 2014, 46, 110-121. [CrossRef]

103. McCabe, M.; Waters, S.; Morris, D.; Kenny, D.; Lynn, D.; Creevey, C. RNA-seq analysis of differential gene expression in liver from lactating dairy cows divergent in negative energy balance. BMC Genom. 2012, 13, 193. [CrossRef] [PubMed]

104. McDougall, S.; LeBlanc, S.; Heiser, A. Effect of prepartum energy balance on neutrophil function following pegbovigrastim treatment in periparturient cows. J. Dairy Sci. 2017, 100, 7478-7492. [CrossRef]

105. McGuffey, R.; Richardson, L.; Wilkinson, J. Ionophores for Dairy Cattle: Current Status and Future Outlook. J. Dairy Sci. 2001, 84, E194-E203. [CrossRef]

106. McNeel, A.K.; Reiter, B.C.; Weigel, D.; Osterstock, J.; Di Croce, F.A. Validation of genomic predictions for wellness traits in US Holstein cows. J. Dairy Sci. 2017, 100, 9115-9124. [CrossRef] [PubMed]

107. Mezzetti, M.; Bionaz, M.; Trevisi, E. Interaction between inflammation and metabolism in periparturient dairy cows. J. Anim. Sci. 2020, 98, S155-S174. [CrossRef] 
108. Ryman, V.E.; Nickerson, S.C.; Kautz, F.M.; Hurley, D.J.; Ely, L.O.; Wang, Y.Q.; Forsberg, N.E. Effect of dietary supplementation on the antimicrobial activity of blood leukocytes isolated from Holstein heifers. Res. Vet. Sci. 2013, 3, 969-974. [CrossRef]

109. Mezzetti, M.; Minuti, A.; Piccioli-Cappelli, F.; Gabai, G.; Trevisi, E. Administration of an Immune Stimulant during the Transition Period Improved Lipid Metabolism and Rumination without Affecting Inflammatory Status. Animals 2019, 9, 619. [CrossRef] [PubMed]

110. Minuti, A.; Ahmed, S.; Trevisi, E.; Cappelli, F.P.; Bertoni, G.; Jahan, N.; Bani, P. Experimental acute rumen acidosis in sheep: Consequences on clinical, rumen, and gastrointestinal permeability conditions and blood chemistry. J. Anim. Sci. 2014, 92, 3966-3977. [CrossRef]

111. Lopreiato, V.; Palma, E.; Minuti, A.; Loor, J.J.; Lopreiato, M.; Trimboli, F.; Morittu, V.M.; Spina, A.A.; Britti, D.; Trevisi, E. Pegbovigrastim Treatment around Parturition Enhances Postpartum Immune Response Gene Network Expression of whole Blood Leukocytes in Holstein and Simmental Cows. Animals 2020, 10, 621. [CrossRef] [PubMed]

112. Minuti, A.; Jahan, N.; Lopreiato, V.; Piccioli-Cappelli, F.; Bomba, L.; Capomaccio, S.; Loor, J.; Ajmone-Marsan, P.; Trevisi, E. Evaluation of circulating leukocyte transcriptome and its relationship with immune function and blood markers in dairy cows during the transition period. Funct. Integr. Genom. 2019, 20, 293-305. [CrossRef] [PubMed]

113. Monteiro, H.F.; Faciola, A.P. Ruminal acidosis, bacterial changes, and lipopolysaccharides. J. Anim. Sci. 2020, 98 , skaa248. [CrossRef]

114. Van Schyndel, S.J.; Carrier, J.; Pascottini, O.B.; Leblanc, S.J. The effect of pegbovigrastim on circulating neutrophil count in dairy cattle: A randomized controlled trial. PLoS ONE 2018, 13, e0198701. [CrossRef]

115. Nace, E.; Nickerson, S.; Kautz, F.; Breidling, S.; Wochele, D.; Ely, L.; Hurley, D. Modulation of innate immune function and phenotype in bred dairy heifers during the periparturient period induced by feeding an immunostimulant for 60 days prior to delivery. Vet. Immunol. Immunopathol. 2014, 161, 240-250. [CrossRef] [PubMed]

116. Nayeri, S.; Schenkel, F.; Fleming, A.; Kroezen, V.; Sargolzaei, M.; Baes, C.; Cánovas, A.; Squires, J.; Miglior, F. Genome-wide association analysis for $\beta$-hydroxybutyrate concentration in Milk in Holstein dairy cattle. BMC Genet. 2019, 20, 58. [CrossRef] [PubMed]

117. Neave, H.; Lomb, J.; von Keyserlingk, M.; Behnam-Shabahang, A.; Weary, D. Parity differences in the behavior of transition dairy cows. J. Dairy Sci. 2017, 100, 548-561. [CrossRef] [PubMed]

118. Neave, H.; Lomb, J.; Weary, D.; LeBlanc, S.; Huzzey, J.; Von Keyserlingk, M. Behavioral changes before metritis diagnosis in dairy cows. J. Dairy Sci. 2018, 101, 4388-4399. [CrossRef] [PubMed]

119. Nightingale, C.R.; Sellers, M.D.; Ballou, M.A. Elevated plasma haptoglobin concentrations following parturition are associated with elevated leukocyte responses and decreased subsequent reproductive efficiency in multiparous Holstein dairy cows. Vet. Immunol. Immunopathol. 2015, 164, 16-23. [CrossRef] [PubMed]

120. Mammi, L.; Guadagnini, M.; Mechor, G.; Cainzos, J.; Fusaro, I.; Palmonari, A.; Formigoni, A. The Use of Monensin for Ketosis Prevention in Dairy Cows during the Transition Period: A Systematic Review. Animals 2021, 11, 1988. [CrossRef] [PubMed]

121. Ortiz-Marty, R.J.; Forsberg, N.E.; Chapman, J.D.; Mullarky, I.K. OmniGen-AF®restores GR-1, L-selectin, and RANTES expression by immunosuppressed murine PMN challenged with lipopolysaccharide in a MyD88-dependent manner. J. Dairy Sci. 2013, 96, 397.

122. Gaddis, K.P.; Cole, J.; Clay, J.; Maltecca, C. Genomic selection for producer-recorded health event data in US dairy cattle. J. Dairy Sci. 2014, 97, 3190-3199. [CrossRef] [PubMed]

123. Pearce, S. The Effects of Heat Stress and Nutritional Status on Metabolism and Intestinal Integrity in Growing Pigs; Iowa State University, Digital Repository: Ames, IA, USA, 2011.

124. Mezzetti, M.; Piccioli-Cappelli, F.; Bani, P.; Amadori, M.; Calamari, L.; Minuti, A.; Loor, J.J.; Bionaz, M.; Trevisi, E. Monensin controlled-release capsule administered in late-pregnancy differentially affects rumination patterns, metabolic status, and cheese-making properties of the milk in primiparous and multiparous cows. Ital. J. Anim. Sci. 2019, 18, 1271-1283. [CrossRef]

125. Pearce, S.C.; Sanz-Fernandez, M.V.; Torrison, J.L.; Wilson, M.E.; Baumgard, L.H.; Gabler, N.K. Dietary organic zinc attenuates heat stress-induced changes in pig intestinal integrity and metabolism12. J. Anim. Sci. 2015, 93, 4702-4713. [CrossRef] [PubMed]

126. Piñeiro, J.; Menichetti, B.; Barragan, A.; Relling, A.; Weiss, W.; Bas, S.; Schuenemann, G. Associations of postpartum lying time with culling, milk yield, cyclicity, and reproductive performance of lactating dairy cows. J. Dairy Sci. 2019, 102, 3362-3375. [CrossRef]

127. Prins, B.; Kuchenbaecker, K.B.; Bao, Y.; Smart, M.; Zabaneh, D.; Fatemifar, G.; Luan, J.; Wareham, N.J.; Scott, R.A.; Perry, J.R.B.; et al. Genome-wide analysis of health-related biomarkers in the UK Household Longitudinal Study reveals novel associations. Sci. Rep. 2017, 7, 11008. [CrossRef] [PubMed]

128. Proudfoot, K.L. Maternal Behavior and Design of the Maternity Pen. Vet. Clin. N. Am. Food Anim. Pract. 2019, 35, 111-124. [CrossRef] [PubMed]

129. Dann, H.; Litherland, N.; Underwood, J.; Bionaz, M.; D'Angelo, A.; McFadden, J.; Drackley, J. Diets During Far-Off and Close-Up Dry Periods Affect Periparturient Metabolism and Lactation in Multiparous Cows. J. Dairy Sci. 2006, 89, 3563-3577. [CrossRef]

130. Putman, A.; Brown, J.; Gandy, J.; Wisnieski, L.; Sordillo, L. Changes in biomarkers of nutrient metabolism, inflammation, and oxidative stress in dairy cows during the transition into the early dry period. J. Dairy Sci. 2018, 101, 9350-9359. [CrossRef] [PubMed] 
131. Trevisi, E.; Amadori, M.; Cogrossi, S.; Razzuoli, E.; Bertoni, G. Metabolic stress and inflammatory response in high-yielding, periparturient dairy cows. Res. Vet. Sci. 2012, 93, 695-704. [CrossRef]

132. Van Raden, P.M.; Cole, J.B.; Gaddis, K.L.P. Net Merit as a Measure of Lifetime Profit: 2014 Revision. Available online: https: / / aipl.arsusda.gov/reference/nmcalc-2014.htm. (accessed on 1 December 2018).

133. Raghupathy, R. Cytokines as Key Players in the Pathophysiology of Preeclampsia. Med. Princ. Pract. 2013, 22, 8-19. [CrossRef] [PubMed]

134. Raszek, M.M.; Guan, L.L.; Plastow, G.S. Use of Genomic Tools to Improve Cattle Health in the Context of Infectious Diseases. Front. Genet. 2016, 7, 30. [CrossRef] [PubMed]

135. Duffield, T.; Rabiee, A.; Lean, I. A Meta-Analysis of the Impact of Monensin in Lactating Dairy Cattle. Part 3. Health and Reproduction. J. Dairy Sci. 2008, 91, 2328-2341. [CrossRef]

136. Rhoads, M.L.; Rhoads, R.P.; VanBaale, M.J.; Collier, R.J.; Sanders, S.R.; Weber, W.J.; Crooker, B.A.; Baumgard, L.H. Effects of heat stress and plane of nutrition on lactating Holstein cows: I. Production, metabolism, and aspects of circulating somatotropin. $J$. Dairy Sci. 2009, 92, 1986-1997. [CrossRef]

137. Rioja-Lang, F.; Roberts, D.; Healy, S.; Lawrence, A.; Haskell, M. Dairy cow feeding space requirements assessed in a Y-maze choice test. J. Dairy Sci. 2012, 95, 3954-3960. [CrossRef]

138. Rodríguez-Jiménez, S.; Haerr, K.; Trevisi, E.; Loor, J.; Cardoso, F.; Osorio, J. Prepartal standing behavior as a parameter for early detection of postpartal subclinical ketosis associated with inflammation and liver function biomarkers in peripartal dairy cows. $J$. Dairy Sci. 2018, 101, 8224-8235. [CrossRef] [PubMed]

139. Rørvang, M.V.; Nielsen, B.L.; Herskin, M.S.; Jensen, M.B. Prepartum Maternal Behavior of Domesticated Cattle: A Comparison with Managed, Feral, and Wild Ungulates. Front. Vet. Sci. 2018, 5, 45. [CrossRef] [PubMed]

140. Ruiz, R.; Tedeschi, L.; Sepúlveda, A. Investigation of the effect of pegbovigrastim on some periparturient immune disorders and performance in Mexican dairy herds. J. Dairy Sci. 2017, 100, 3305-3317. [CrossRef]

141. Ruotsalainen, S.E.; Gen, F.; Partanen, J.J.; Cichonska, A.; Lin, J.; Benner, C.; Surakka, I.; Reeve, M.P.; Palta, P.; Salmi, M.; et al. An expanded analysis framework for multivariate GWAS connects inflammatory biomarkers to functional variants and disease. Eur. J. Hum. Genet. 2021, 29, 309-324. [CrossRef] [PubMed]

142. Saha, S.; Gallo, L.; Bittante, G.; Schiavon, S.; Bergamaschi, M.; Gianesella, M.; Fiore, E. A Study on the Effects of Rumen Acidity on Rumination Time and Yield, Composition, and Technological Properties of Milk from Early Lactating Holstein Cows. Animals 2019, 9, 66. [CrossRef]

143. Soriani, N.; Trevisi, E.; Calamari, L. Relationships between rumination time, metabolic conditions, and health status in dairy cows during the transition period. J. Anim. Sci. 2012, 90, 4544-4554. [CrossRef] [PubMed]

144. Stangaferro, M.; Wijma, R.; Caixeta, L.; Al Abri, M.; Giordano, J. Use of rumination and activity monitoring for the identification of dairy cows with health disorders: Part III. Metritis. J. Dairy Sci. 2016, 99, 7422-7433. [CrossRef]

145. A Thompson-Crispi, K.; Sargolzaei, M.; Ventura, R.; Abo-Ismail, M.; Miglior, F.; Schenkel, F.; A Mallard, B. A genome-wide association study of immune response traits in Canadian Holstein cattle. BMC Genomics 2014, 15, 559. [CrossRef] [PubMed]

146. Trevisi, E.; Amadori, M.; Riva, F.; Bertoni, G.; Bani, P. Evaluation of innate immune responses in bovine forestomachs. Res. Vet. Sci. 2014, 96, 69-78. [CrossRef]

147. Trevisi, E.; Minuti, A. Assessment of the innate immune response in the periparturient cow. Res. Vet. Sci. 2018, 116, 47-54 [CrossRef] [PubMed]

148. Trevisi, E.; Moscati, L.; Amadori, M. Disease-Predicting and Prognostic Potential of Innate Immune Responses to Noninfectious Stressors: Human and Animal Models; Amadori, M., Ed.; Elsevier: Amsterdam, The Netherlands, 2016.

149. Trevisi, E.; Riva, F.; Filipe, J.F.S.; Massara, M.; Minuti, A.; Bani, P.; Amadori, M. Innate immune responses to metabolic stress can be detected in rumen fluids. Res. Vet. Sci. 2018, 117, 65-73. [CrossRef]

150. Trevisi, E.; Zecconi, A.; Bertoni, G.; Piccinini, R. Blood and milk immune and inflammatory profiles in periparturient dairy cows showing a different liver activity index. J. Dairy Res. 2010, 77, 310-317. [CrossRef]

151. Trevisi, E.; Zecconi, A.; Cogrossi, S.; Razzuoli, E.; Grossi, P.; Amadori, M. Strategies for reduced antibiotic usage in dairy cattle farms. Res. Vet. Sci. 2014, 96, 229-233. [CrossRef]

152. Trimboli, F.; Morittu, V.M.; Di Loria, A.; Minuti, A.; Spina, A.A.; Piccioli-Cappelli, F.; Trevisi, E.; Britti, D.; Lopreiato, V. Effect of Pegbovigrastim on Hematological Profile of Simmental Dairy Cows during the Transition Period. Animals 2019, 9, 841. [CrossRef]

153. Tucker, C.B.; Weary, D.M.; Von Keyserlingk, M.A.G.; Beauchemin, K.A. Cow comfort in tie-stalls: Increased depth of shavings or straw bedding increases lying time. J. Dairy Sci. 2009, 92, 2684-2690. [CrossRef]

154. Ventura, B.; von Keyserlingk, M.; Schuppli, C.; Weary, D. Views on contentious practices in dairy farming: The case of early cow-calf separation. J. Dairy Sci. 2013, 96, 6105-6116. [CrossRef] [PubMed]

155. Wang, X.; Li, X.; Zhao, C.; Hu, P.; Chen, H.; Liu, Z.; Liu, G.; Wang, Z. Correlation between Composition of the Bacterial Community and Concentration of Volatile Fatty Acids in the Rumen during the Transition Period and Ketosis in Dairy Cows. Appl. Environ. Microbiol. 2012, 78, 2386-2392. [CrossRef] [PubMed]

156. Wang, Y.; Puntenney, S.B.; Burton, J.L.; Forsberg, N.E. Ability of a commercial feed additive to modulate expression of innate immunity in sheep immunosuppressed with dexamethasone. Animal 2007, 1, 945-951. [CrossRef]

157. Wankhade, P.R.; Manimaran, A.; Kumaresan, A.; Jeyakumar, S.; Ramesha, K.; Sejian, V.; Rajendran, D.; Varghese, M.R. Metabolic and immunological changes in transition dairy cows: A review. Vet. World 2017, 10, 1367-1377. [CrossRef] 
158. Wathes, D.C.; Cheng, Z.; Bourne, N.; Taylor, V.J.; Coffey, M.P.; Brotherstone, S. Differences between primiparous and multiparous dairy cows in the inter-relationships between metabolic traits, milk yield and body condition score in the periparturient period. Domest. Anim. Endocrinol. 2007, 33, 203-225. [CrossRef] [PubMed]

159. Weary, D.M.; Huzzey, J.M.; von Keyserlingk, M.A.G. BOARD-INVITED REVIEW: Using behavior to predict and identify ill health in animals1. J. Anim. Sci. 2009, 87, 770-777. [CrossRef]

160. Weller, J.; Ezra, E.; Ron, M. Invited review: A perspective on the future of genomic selection in dairy cattle. J. Dairy Sci. 2017, 100, 8633-8644. [CrossRef] [PubMed]

161. Wheelock, J.B.; Rhoads, R.P.; VanBaale, M.J.; Sanders, S.R.; Baumgard, L.H. Effects of heat stress on energetic metabolism in lactating Holstein cows. J. Dairy Sci. 2010, 93, 644-655. [CrossRef]

162. Egger-Danner, C.; Cole, J.; Pryce, J.; Gengler, N.; Heringstad, B.; Bradley, A.; Stock, K. Invited review: Overview of new traits and phenotyping strategies in dairy cattle with a focus on functional traits. Animal 2015, 9, 191-207. [CrossRef]

163. Wisnieski, L.; Norby, B.; Pierce, S.; Becker, T.; Gandy, J.; Sordillo, L. Predictive models for early lactation diseases in transition dairy cattle at dry-off. Prev. Vet. Med. 2019, 163, 68-78. [CrossRef] [PubMed]

164. Tetens, J.; Heuer, C.; Heyer, I.; Klein, M.; Gronwald, W.; Junge, W.; Oefner, P.J.; Thaller, G.; Krattenmacher, N. Polymorphisms within the APOBR gene are highly associated with milk levels of prognostic ketosis biomarkers in dairy cows. Physiol. Genom. 2015, 47, 129-137. [CrossRef]

165. Wisnieski, L.; Norby, B.; Pierce, S.J.; Becker, T.; Sordillo, L.M. Prospects for predictive modeling of transition cow diseases. Anim. Health Res. Rev. 2019, 20, 19-30. [CrossRef]

166. Zebeli, Q.; Ghareeb, K.; Humer, E.; Metzler-Zebeli, B.; Besenfelder, U. Nutrition, rumen health and inflammation in the transition period and their role on overall health and fertility in dairy cows. Res. Vet. Sci. 2015, 103, 126-136. [CrossRef]

167. Zhang, G.; Hailemariam, D.; Dervishi, E.; Goldansaz, S.A.; Deng, Q.; Dunn, S.M.; Ametaj, B.N. Dairy cows affected by ketosis show alterations in innate immunity and lipid and carbohydrate metabolism during the dry off period and postpartum. Res. Vet. Sci. 2016, 107, 246-256. [CrossRef]

168. Zhang, Q.; Cai, Z.; Lhomme, M.; Sahana, G.; Lesnik, P.; Guerin, M.; Fredholm, M.; Karlskov-Mortensen, P. Inclusion of endophenotypes in a standard GWAS facilitate a detailed mechanistic understanding of genetic elements that control blood lipid levels. Sci. Rep. 2020, 10, 18434. [CrossRef] [PubMed]

169. Zinicola, M.; Korzec, H.; Teixeira, A.; Ganda, E.; Bringhenti, L.; Tomazi, A.; Gilbert, R.; Bicalho, R. Effects of pegbovigrastim administration on periparturient diseases, milk production, and reproductive performance of Holstein cows. J. Dairy Sci. 2018, 101, 11199-11217. [CrossRef]

170. Zwald, N.R.; Weigel, K.A.; Chang, Y.M.; Welper, R.D.; Clay, J.S. Genetic Selection for Health Traits Using Producer-Recorded Data. I. Incidence Rates, Heritability Estimates, and Sire Breeding Values. J. Dairy Sci. 2004, 87, 4287-4294. [CrossRef] 